\title{
Research Article \\ The Change in post 1980 Economic Development and Innovation Studies towards Evolutionary Economics
}

\author{
Maria Elizabeth Eggink \\ Tshwane University of Technology, Nelspruit, South Africa \\ Correspondence should be addressed to: Maria Elizabeth Eggink; egginkme@tut.ac.za
}

Received 5 December 2012; Accepted 15 January 2013; Published 25 March 2013

Academic Editor: Mad Khir Johari Bin Abddulah Sani

Copyright (C) 2013 Maria Elizabeth Eggink. Distributed under Creative Commons CC-BY 3.0

\begin{abstract}
The role of innovation in economic growth is perceived differently by the different schools of thought. The neoclassical theories emphasise equilibrium in the economy and cannot explain the role of innovation, because the effect of innovation is actually a disturbance of equilibrium. Schumpeter (1961) has shown that growth and development can only take place if the economy is constantly disturbed to an out-of-equilibrium phase. In some of the later neoclassical theories, innovation was considered as a factor that causes growth, but was treated as an exogenous factor. The "new growth theories" were developed later, including innovation as an endogenous factor, but these theories were still based on the equilibrium principle. In the Schumpeterian and neoSchumpeterian theories, innovation is treated as endogenous to the economy. Schumpeter had not been acknowledged as a mainstream economist during the time that he developed and first published his theory. It was not until the 1980s that economists started paying attention to his works and to the importance of innovation in development. The aim of this article is to determine how the studies since 1980 have changed regarding their foundation in the different schools of thought. A methodological and theoretical review is conducted of post 1980 empirical studies that determined the relationship between innovation and economic development. It was found that many empirical studies still make use of neoclassical equilibrium models and that the studies that consider the complexity of the innovation system are not yet sufficiently developed to explain the relationship between innovation and economic development.
\end{abstract}

JEL Codes: B52 and 030

Keywords: Innovation, economics development, neo-Schumpeterian theories.

Cite this Article as: Maria Elizabeth Eggink (2013), "The Change in post 1980 Economic Development and Innovation Studies towards Evolutionary Economics," Journal of Economics Studies and Research, Vol. 2013 (2013), Article ID 702172, DOI: 10.5171/2013.702172 


\section{Introduction}

Freeman, (1982:3) has it that innovation is critical for sustainable economic growth, for the improvement of quality of life, for the long-term conservation of resources and for the improvement of the environment. He believes that the role of innovation in the reduction or elimination of mass poverty of Asia, Africa and Latin America, as well as in other parts of the world, must not be overlooked. However, the role of innovation in economic growth is perceived differently by the different schools of thought.

Innovation plays no significant role in the classical theories, and even less in the neoclassical theories (Verspagen, 2005:489). These theories, which emphasise equilibrium in the economy, cannot explain the role of innovation, because the effect of innovation is actually a disturbance of equilibrium. Schumpeter (1961) has shown that growth and development can only take place if the economy is constantly disturbed to an out-ofequilibrium phase. In some of the later neoclassical theories, innovation was considered as a factor that causes growth, but was treated as an exogenous factor (Brue, 2000:499; Verspagen, 2005:489; Nafziger, 2006:153; Hanusch and Pyka, 2007b:21; Solow, 2008). The "new growth theories" were developed later, including innovation as an endogenous factor, but these theories were still based on the equilibrium principle (Romer, 1986; Freeman, 2002:193; Fagerberg et al., 2009:19). In the Schumpeterian and neoSchumpeterian theories, innovation is treated as endogenous to the economy (Schumpeter, 1939:86; Carlsson, 2007:859). Schumpeter had not been acknowledged as a mainstream economist during the time that he developed and first published his theory. It was not until the 1980 s that economists started paying attention to his works and to the importance of innovation in development. The neo-Schumpeterian theory is, as might be expected, based on Schumpeter's theory. The difference between the Schumpeterian and the neo-
Schumpeterian theories is mostly the fact that Schumpeter did not see innovation as taking place in a system. The neoSchumpeterian thinking is about studying innovation within a system with interaction among different role players (Carlsson, 2007:859). The neo-Schumpeterian theories are classified under the evolutionary economics school of thought (Freeman, 2008:236).

The renewed interest in the role of innovation in economic development since 1980 resulted in a number of publications. The aim of this article is to determine how the studies since 1980 have changed regarding their foundation in the different schools of thought.

The research questions addressed in this study are the following:

i) What is the historical relationship between innovation and economic development?

ii) How do the different empirical studies since 1980 regard the relationship between innovation and economic development?

iii) How does the innovation system concept affect the studying of the innovationeconomic development relationship?

\section{Research Methodology}

The research methodology applied is qualitative in nature. A literature review is done to determine the historical patterns of innovation and economic development to explain and provide the background for the importance of innovation in economic development. This review includes a critical discussion on the relationship of innovations to the long wave theories to provide evidence of the role of innovation in economic development. A methodological and theoretical review is thereafter conducted of post 1980 empirical studies that determined the relationship between innovation and 
economic development. This review is aimed at establishing if these studies are following the methodological and theoretical trends of evolutionary economics. Data consist of secondary sources, including reports on empirical studies conducted since 1980 on the relationship between innovation and economic development. The collection of reports was done until saturation was reached and data started repeating.

\section{Historical Trends in Innovation and Economic Development}

According to Ray (1980:16), “... economic history provides sufficient evidence for underlying the economic importance - in long cycles or otherwise - of innovation, of its role as a driving force as well as the consequences of its relative neglect".

The importance of innovation for the increase in per capita income, population growth and improvement in welfare is clear from the evidence over the millennia. The GDP growth per capita and the population growth were very low during the years between 1 and $1400 \mathrm{AD}$, but between 1400 and 1500 the world population and GDP per capita started increasing. Innovations in the following areas, inter alia, resulted in these changes: better hygiene, more efficient ways to harness wind and water power to improve and to increase human and animal energy, improvement in agricultural techniques such as irrigation, seed improvement and multiple cropping, improvements in shipbuilding and navigation technology, all led to increased trade, expanding markets and specialization. Again, since the 1800s, the GDP per capita growth, as well as the population growth, started increasing suddenly and exponentially. Growth of incomes was accompanied by unprecedented increases in population and exponential increases in the rate of scientific discoveries. These increases again can be linked to innovations, this time to such developments as the invention of the steam engine that led to the use of fossil fuel energy for productive tasks and, thereafter, to the Industrial Revolution (Fogel, 1999:2;
Maddison, 2001:241\&261; The World Bank, 2010:32-34).

These are merely a few examples of the innovations that led to rapid increase in both population and economic growth. Yet it is clear that, just as the economic development increased, the number of innovations has also increased exponentially since the 1800s. Innovation played an important role in economic history, in economic growth and in economic development, particularly when considering the improvement in living standards that these innovations birthed.

\section{Evidence of the Relationship of Innovation to Long Waves}

When studying the role of innovation in economic development, it is worthwhile investigating the relationship of innovation to the long-term fluctuations in economic activity. Kondratiev (1935:111) empirically established certain long wave relationships, but did not imply that the results explained the trend of the long waves. One of the relationships is that of discoveries or inventions with long waves. Kondratiev stated,

"During the recession of the long waves, an especially large number of important discoveries and inventions in the technique of production and communication are made, which, however, are usually applied on a large scale only at the beginning of the next long upswing".

Kondratiev (1935:112) qualified the "discoveries and inventions" that are presumed as "changes in technique of production" by calling them "relevant scientific-technical discoveries and inventions". This application of the invention or discovery that takes place during the upswing is most likely to refer to innovation. Kondratiev (1935:112) was of the opinion that, although "changes in technique" were very important for "capitalistic development", inventions alone would not achieve development. He believed that, first, 
the economic conditions must be favourable for the application of the invention to take place. The implication is that Kondratiev shared Schumpeter's (1961) view on the importance of innovation, rather than invention, in the theory of long waves. However, they differed in their opinion of the relationship between the phase of the wave and innovation.

Schumpeter (1961:223-228) began his theory on the business cycle with the conviction that economic development fluctuated and did so in an unevenly manner because new combinations appear discontinuously in groups or as swarms and that entrepreneurs appear in clusters because new entrepreneurs facilitate the appearance of other entrepreneurs. According to Van Duijn (1983:99), this view of Schumpeter was the link between innovation and cyclical fluctuations, in that, "cycles arise because innovations appear in bunches".

Schumpeter (1939:166-167) also believed that there was not merely one single cycle but that cycles of different length existed contemporaneously. Schumpeter's view was that innovation took place in all periods, but that there were many more innovations in the recovery periods. However, there are a number of economists who differ with Schumpeter. Mensch, for example, believes that innovation takes place mostly during the depression period and during the recovery period, while Schmookler believes that innovation takes place mainly during the prosperity period (Sundbo, 1998:40-42). Van Duijn (1983:174-179) has found, in his analysis of Mensch and Schmookler, that these two studies differ due largely to the type of innovation under consideration. Mensch focused mainly on product innovation in new sectors, taking place during the prosperity phase, and on process innovation in old sectors that takes place mainly at the end of the depression phase. Schmookler, on the other hand, focused on product innovation in old sectors.
Ray (1980:13-16) used historical data to prove that there was a relationship between these major innovations and the development in the different countries. Van Duijn (1983:174-179) concluded, with empirical support, that innovation mostly rose at the end of the depression period and during the recovery phase, and then declined during the prosperity phase (Van Duijn, 1983). Freeman, Clark and Soete arrived at the same conclusion from their empirical analysis (Sundbo, 1998:42).

However, the contribution of innovation to economic development is proved by some studies of the relationship of innovation paradigms to long waves. Sundbo (1998) explained the innovation theory in terms of three different paradigms in the innovation theory. Sundbo (1998:46-104) linked his study of innovation paradigms with the Kondratiev waves. He believed that each Kondratiev wave was "very probably linked to its own innovation system".

Freeman and Perez (2008:38-73), in agreement with Sundbo, stated that history could not only be characterised by different "clusters of innovation" or "technology systems", but showed that the changes could be described as different "techno-economic paradigms".

Even though it can be concluded that all kinds of innovation take place at all times, some kinds may suit a certain economic and social climate better than others will, for the economic and social climates are in constant flux. It may be useful to know which paradigm, or kind of innovation, best suits the existing economic and social climates, in order to stimulate the kind of innovation needed to create development at the existing point in the cycle. The studies of major innovations in history have provided proof of the contribution of innovations to the end of depression periods, thus leading thereafter to prosperity phases. 


\section{Empirical Studies on the Relationship between Innovation and Economic Development}

The empirical studies on the relationship between innovation and economic development vary according to the different schools of thought within which the original discussion is based. Although the studies since the 1980s-90s in the different schools of thought largely agree concerning innovation being important for economic development, they differ in their opinions of the degree of importance of innovation. The most important difference amongst these schools of thought regarding the role of innovation in economic development lies in the process. Their disagreements can be analysed as:

(i) How innovation contributes to economic development;

(ii) The neoclassical view of treating innovation as an exogenous variable;

(iii) The new growth theories of incorporating innovation as an endogenous variable but still in an equilibrium model;

(iv) The Schumpeterian view of innovation as an endogenous variable disturbing equilibrium; and

(v) The neo-Schumpeterian view of innovation as a non-linear relationship among many determinants in an innovation system.

There are many studies that still make use of the neoclassical models and new growth models, despite the shortcomings of these models in explaining the process of innovation. These can best be typified by studies comparing countries and those at firm level:

(i) LeBel (2008) built onto the endogenous growth model of Romer (1986) and added an innovation index as an endogenous factor. LeBel tested his model empirically by using a panel regression model on a sample of 103 countries for the 1980-2005 period. LeBel (2008:334; 338) found that there was a positive role of creative innovation in economic growth. Cameron's (1996) conclusion from his survey of empirical studies corresponds with the findings of LeBel. Cameron (1996:10) believed that innovation made a significant contribution to growth. The study of Ahmed and Suardi (2007) was also based on an endogenous growth model, using a Cobb-Douglas production function and the Solow model as the baseline. Ahmed and Suardi tested 28 sub-Saharan African countries and found, inter alia, that the differences in per capita growth rates across these countries could possibly arise from differences in the technological growth rates.

Hulten and Isaksson (2007) also followed the endogenous growth theory to determine the reasons for the per capita income differentials among countries. They studied 112 countries over the period 1970-2000 and found that the share of total factor productivity (TFP) growth was always greater than that of capital deepening for all countries tested across income classifications. The World Bank (2010:43) concluded from their study that the TFP was the residual for the growth in output that was not explained by the growth inputs, that innovation was approximately proxied by TFP and that innovation was the major contributor to the differences in development across countries.

(ii) Crespi and Zuñiga (2010) conducted research at firm level testing the relationship between innovation and productivity empirically. Their study was conducted across 6 Latin American countries, and used micro data from innovation surveys. They treated innovation as an endogenous factor, together with labour, capital and 
knowledge, in a Cobb-Douglas function. Productivity was measured as "sales per employee" and they found, "a very strong association between innovation and productivity" (Crespi and Zuñiga, 2010:3; 31). A similar study to the work of Crespi and Zuñiga is that of Lööf and Heshmati (2002), who sought to determine the relationship between innovation and performance at firm level, but who also compared the outcomes for manufacturing and service firms, as well as for "new to the firm" and "new to the market" categories. The data for their study was collected as an experiment enlargement of the second European Community Innovation Survey conducted by Statistics Sweden. The data collection covered the period 1996 to 1998. Lööf and Heshmati (2002:19) confirmed the positive relationship between innovation and productivity growth for service firms, but stated that this positive relationship exist for manufacturing firms only if innovation is new to the market.

The neoclassical and new growth theories were dominant in the twentieth century. The popularity of these theories may have been due to their analytical abilities and mechanistic design making the approach convincing. However, in the analysis of dynamic phenomena and complex systems, these theories were inadequate (Hanusch and Pyka, 2007a:275). The diversity and unpredictability of innovations made their application even more difficult. According to Baumol, (2002:2), "(e)conomic theorists have always found it difficult to deal mathematically with heterogeneous products ... [I]nnovation is perhaps the product that attains the ultimate lack of uniformity. If two products or processes are very similar they will not both be considered innovative. Innovative activity, by definition, is the attempt to introduce something that did not exist before ...". Verspagen (1992:649), added, "(i)f technological expectations are not rational, and the consequences of technological events cannot be calculated in advance, the equilibrium growth path predicted by the new growth models ... is much less likely to occur".

The neo-Schumpeterian theories treat innovation as a much more complex system and as one that cannot be reduced or simplified as takes place in the neoclassical models of growth. According to Hanusch and Pyka, (2007a:278), simple systems are "decomposable" whereas complex systems are "irreducible". They explain that, "neglecting a single part has severe consequences for their understanding". Some economists try to use neoclassical models for explaining the complexity of innovation systems. However, Nelson (1996:15) states that, "(w)hile it is simple to extend the neoclassical model to include many sectors, the basic logic of that model is committed to continuing equilibrium, not resource reallocation driven by prevailing disequilibrium". Hanusch and Pyka (2007a:278) further indicate that simple systems can be predicted whereas complex systems are fundamentally unpredictable due to the non-linearities caused by interactions and feedbacks.

The systems approach of studying innovation, with its origin mostly during the 1980s and 1990s, can be regarded as being still in its infancy. It follows, perhaps, that there is currently no comprehensive agreement in literature on how innovation systems should be studied empirically. Some of the studies that attempt to link innovation input or output with economic development make use of, or develop an, index to represent the complexity of the innovation system. The following may be offered as examples of this approach: Howells' (2005:1222) empirical study of a correlation between the Revealed Regional Summary Innovation Index (RRSII) and the relative per capita GDP (for selected regions across the European Union) indicated a clear correlation between innovation and economic activity and performance. Archibugi and Coco (2004) developed the ArCo index and empirically tested the 
Journal of Economics Studies and Research

correlation between the ArCo index and the GDP per capita of 162 countries over the period 1990-2000. They concluded that there was a very strong association between per capita technological capabilities and GDP. Fagerberg and Srholec's (2008) factor analysis combined several indicators of innovation capability into a factor that they called "innovation system". They found that there was a very close correlation between the factor score on "innovation system" and the GDP per capita of the 115 countries tested in the period between 1992 and 2004 . Although Archibugi and Coco, (2005:176), admitted that, "... there (was) no single number that can provide comprehensive information of the whole technological capabilities of a country", they find that "synthetic indicators" could, "..., despite the limitations, and if taken with due caution, ... help to understand the reality of certain situations, and ... assist in devising strategic decisions".

Qualitative change, and not only quantitative change, is important in the analysis of the innovation system. Hasan and Tucci (2010) used global patent data to investigate empirically the importance of both the quantity and quality of innovation to economic growth under various economic structures and stages of economic development. A sample of 58 countries for the period 1980-2003 was used by them and the results from a correlation matrix and regression analysis indicated that those countries hosting firms with "higher quality" patents have higher economic growth and that those countries that "increase the level" of patenting also witnessed a concomitant increase in economic growth. Hasan and Tucci (2010:1273) concluded that quantity and quality of innovation were both associated with economic growth.

Although there is evidence from empirical studies that innovation contributes to economic development, it is important to note that not all innovation leads to development. There are exceptions, such as inappropriate technology, that may lead to economic growth, but may have a negative effect on development. This is particularly the case in developing countries where importation of advanced technology that leads to large-scale capital-intensive industries can create an undesirable dual economy (that is, a prosperous modern sector and an impoverished traditional sector) (Akube, 2000).

\section{Conclusion}

In this study, the relationship between innovation and economic development was first indicated by the major innovations in history and the economic development components per capita GDP growth and population growth. It was shown that since the 1800s, the GDP per capita growth, as well as the population growth, began to increase both unexpectedly and exponentially. These increases are linked to innovations such as the development of the steam engine that led to the use of fossil fuel energy for productive tasks and thereafter, to the Industrial Revolution. This historical overview of major innovations provided proof of the economy's dependence on innovation for development.

The relationship between innovation and economic growth was proven by an understanding of the long wave and innovation paradigm views. Schumpeter's theory, with the support of other economists, demonstrated that innovation took place in all periods, but that there were more innovations in the recovery period.

The evidence from different empirical studies since 1980 indicated that the studies based on the later neoclassical models or the new growth models do indeed show a positive relationship between innovation and economic growth. Nevertheless, these studies are ultimately founded upon simple systems of equilibrium models. Equilibrium models cannot adequately explain innovation's role in economic development as innovation is the essential factor that, through disturbing equilibrium, leads to economic development. Where the neoclassical models do have innovation as an exogenous factor, the new 
growth models incorporated innovation as an endogenous factor, but still using an equilibrium model.

The complexity of the relationship between innovation and economic growth can best be described by the neo-Schumpeterian views, thus indicating the desirability of innovation being studied from a system perspective. The neo-Schumpeterian economists study innovation as a complex non-linear relationship among different actors or role players. Evidence has been given of empirical studies indicating a positive relationship between innovation and economic development. In some empirical studies, innovation has been reduced to an index of different determinants, but innovation capabilities cannot be reduced to a single number and there are quantitative as well as the qualitative differences in innovation systems.

The process of evolution in economics to accept innovation as an endogenous variable in the economic development theories and to understand that innovation has no role in an equilibrium model is not yet complete. There is a movement towards understanding the complexity of the role of innovation in economic development, but due to the difficulty of measuring the performance of the complex innovation system and the difficulty of predicting its effect on economic development, many economists resist the changes of the evolution by relying on other models such as the new growth models. Unfortunately, by ignoring the complexity of the innovation system, the results of predicting the system's effect on economic development will not be reliable.

\section{References}

Ahmed, A. D. \& Suardi, S. (2007). "Sources of Economic Growth and Technology Transfer in Sub Saharan Africa," South African Journal of Economics 75(2), 159-178.

Akube, A. (2000). “Appropriate Technology for Socioeconomic Development in Third
World Countries," [Online]. The Journal of Technology Studies, 26(1), [Retrieved March 9, 2012]. Available: http://scholar.lib.vt.edu/ejournals/JOTS/Wi nter-Spring-2000/akube.html.

Archibugi, D. \& Coco, A. (2004). “A New Indicator of Technological Capabilities for Developed and Developing Countries (ArCo)," World Development, 32(4), 629-654.

Archibugi, D. \& Coco, A. (2005). "Measuring Technological Capabilities at the Country Level: A Survey and a Menu for Choice," Research Policy, 34, 175-194.

Baumol, W. J. (2002). "Towards Microeconomics of Innovation: Growth Engine Hallmark of Market Economics," Atlantic Economic Journal, 30(1).

Brue, L. S. (2000). 'The Evolution of Economic Thought,' 6th ed., Thomson, USA.

Cameron, G. (1996). Innovation and Economic Growth, [Online]. London School of Economics and Political Science, Centre for Economic Performance, London, Discussion paper, no. 277, [Retrieved January 24, 2011]. Available: http://eprints.lse.ac.uk/20685/1/Innovation _and_Economic Growth.pdf.

Carlsson, B. (2007). "Innovation Systems: A Survey of the Literature from a Schumpeterian Perspective," in Hanusch, H. and Pyka, A. (eds.), Elgar companion to NeoSchumpeterian economics, 857-871, Edward Elgar, Cheltenham.

Crespi, G. \& Zuñiga, P. (2010). "Innovation and Productivity: Evidence from Six Latin American Countries," Inter-American Development Bank, Washington, (InterAmerican Development Bank working paper, no. IDB-WP-218).

Fagerberg, J. \& Srholec, M. (2008). "National Innovation Systems, Capabilities and Economic Development," Research Policy, 37, 1417-1435. 
Fagerberg, J., Srholec, M. \& Verspagen, B. (2009). "Innovation and Economic Development," University of Oslo, Oslo, (TIK working papers on innovation studies, no. 20090723), [Retrieved February 21,2011], Available:

http://ideas.repec.org/s/tik/inowpp.html.

Fogel, R. W. (1999). "Catching up with the Economy," American Economic Review, 89(1), 1-21.

Freeman, C. (1982). 'The Economics of Industrial Innovation,' Frances Pinter, London.

Freeman, C. (2002). "Continental, National and Sub-National Innovation Systems Complementarity and Economic Growth," Research Policy, 31,191-211.

Freeman, C. (2008). 'Systems of Innovation: Selected Essays in Evolutionary Economics,' Edward Elgar, Cheltenham.

Freeman, C. \& Perez, C. (2008). 'Structural Crises of Adjustment, Business Cycles and Investment Behaviour,' in Freeman, C., Systems of innovation: Selected essays in evolutionary economics, 38-73, Edward Elgar, Cheltenham.

Hanusch, H. \& Pyka, A. (2007a). "Principles of Neo-Schumpeterian Economics," Cambridge Journal of Economics, 31, 275-289.

Hanusch, H. \& Pyka, A. (2007b). Schumpeter, Joseph Alois (1883-1950), in Hanusch, H. and Pyka, A. (eds.). Elgar Companion to NeoSchumpeterian Economics, 19-26, Edward Elgar, Cheltenham.

Hasan, I. \& Tucci, C. L. (2010). "The Innovation-Economic Growth Nexus: Global Evidence," Research Policy, 39, 1264-1276.

Howells, J. (2005). "Innovation and Regional Economic Development: A Matter of Perspective," Research Policy, 34, 1220-1234.

Hulten, C. R. \& Isaksson, A. (2007). "Why Development Levels Differ: The Sources of
Differential Economic Growth in a Panel of High and Low Income Countries," [Online]. National Bureau of Economic Research, Cambridge, (National Bureau of Economic Research working paper, no. 13469), [Retrieved February 16, 2011]. Available: http://www.nber.org/papers/w13469.

Kondratiev, N. D. \& Stolper, W. F. (1935). "The Long Waves in Economic Life," Translated by WF. Stolper, The Review of Economic Statistics, 17(6), 105-115.

LeBel, P. (2008). "The Role of Creative Innovation in Economic Growth: Some International Comparisons," Journal of Asian Economics, 19, 334-347.

Lööf, H. \& Heshmati, A. (2002). “On the Relationship between Innovation and Performance: A Sensitivity Analysis," Economics of Innovation and New Technology, 15(4-5), 317-344.

Maddison, A. (2001). The World Economy: A Millennial Perspective, OECD, Paris.

Nafziger, E. W. (2006). Economic Development, 4th ed., Cambridge University Press, Cambridge.

Nelson, R. R. (1996). The Sources of Economic Growth, Harvard University Press, London.

Ray, G. F. (1980). "Innovation as the Source of Long Term Economic Growth," Long range planning, 13(2), 9-19.

Romer, P. M. (1986). "Increasing Returns and Long-Run Growth," The Journal of Political Economy, 94(5), 1002-1037.

Schumpeter, J. A. (1939). Business Cycles, vol. 1: A Theoretical, Historical, and Statistical Analysis of the Capitalist Process, McGrawHill, New York.

Schumpeter, J. A. (1961). 'The Theory of Economic Development: An Inquiry into Profits, Capital, Credit, Interest and the 
Business Cycle,' Translated by R. Opie, Harvard University Press, USA.

Solow, R. M. (2008). 'Technical Change and the Aggregate Production Function,' in Link, AN. (ed.)," The economic theory of invention and innovation, 18-26, Edward Elgar, Cheltenham.

Sundbo, J. (1998). The Theory of Innovation: Entrepreneurs, Technology and Strategy, Edward Elgar, Cheltenham.

The World Bank. (2010). "Innovation Policy: A Guide for Developing Countries," The World Bank, Washington.

Van Duijn, J. J. (1983). The Long Wave in Economic Life, George Allen \& Unwin, London.

Verspagen, B. (1992). "Endogenous Innovation in Neo-Classical Growth Models: A Survey," Journal of Macroeconomics, 14(4), Fall, 631-662.

Verspagen, B. (2005). "Innovation and Economic Growth," in Fagerberg, J., Mowery, DC. and Nelson, RR. (eds.),The Oxford handbook of innovation, 487-514, Oxford University Press, New York. 